DOI: $10.21802 / \operatorname{artm} .2019 .2 .10 .136$.

УДК $378.147+614.253 .4$

\title{
ОРГАНІЗАЦІЯ САМОСТІЙНОЇ РОБОТИ СТУДЕНТІВ ЯК СКЛАДОВА ПРОФЕСІЙНОЇ ПІДГОТОВКИ МАЙБУТНІХ ПРОВІЗОРІВ
}

\author{
В.А. Сологуб
}

Івано-Франківський начіональний медичний університет, кафедра фармачії,

м. Івано-Франківськ, Украӥна,

ORCID.org/0000-0001-7815-1587,

e-mail: nika.solo.ifnmu2021@gmail.com

Резюме. Самостійна робота - один зі способів вивчення дисципліни, невід’ємна частина навчального процесу. Це дозволяє глибоко засвоїти матеріал, поглибити вміння та навички в пізнавальній діяльності, активізувати творче мислення та ініціативу; сприяє виробленню власних прийомів і методів пізнання, вчить раціонально організовувати та контролювати свій робочий час.

Відповідно до Положення "Про організацію навчального процесу у вищих навчальних закладах", самостійна робота студента $є$ основним засобом засвоєння студентом навчального матеріалу в час, вільний від обов'язкових навчальних занять.

Цілеспрямована сукупність дій студента під керівництвом викладача на основі використання засобів супроводу навчального процесу передбачає самостійність - можливість здійснювати самостійну роботу на основі формування якостей рефлексивного керування, вивчення методів управління навчально-творчою діяльністю студентів, набуття практичних навичок з аналізу і оцінки якості освітнього процесу за критеріями європейського освітнього простору.

Серед заходів - засвоєння в повному обсязі навчальної програми, визначення ефективної методики і методології викладання навчальних дисциплін в системі університетської освіти іï організації 3 урахуванням сучасних вимог щодо якості загальних та професійних компетентностей, які відіграють суттєву роль у становленні майбутнього фахівця вищого рівня кваліфікації.

У статті розглядаються особливості організації самостійної роботи студентів з урахуванням сучасних вимог та умов навчання, методи її ефективної організації як невід’ємної складової в системі освітнього середовища.

Ключові слова: самоосвіта, самоконтроль, інформаційні технології навчання.

Вступ. Болонською декларацією визнана важливість освіти та освітнього співробітництва як першорядна умова в розвитку та зміцненні стабільних, миролюбних та демократичних суспільств Свропи і всього світу. Програма дій щодо реалізації положень Болонської декларації в системі вищої освіти і науки України передбачає як одне з основних завдань - входження національної системи освіти і науки в європейський простір «постійного навчання впродовж всього життя».

Навчання у вищих навчальних закладах певною мірою пов'язане з проблемою адаптації. Студенти вищих медичних і фармацевтичних закладів, вступивши до вищого навчального закладу, пристосовуються впродовж всіх років навчання до нових для себе умов, що запускають адаптаційні процеси в організмі, й особистості повинні керуватись при цьому самодисципліною і самоконтролем свого часу як самостійною складовою.

Студенти вищих медичних та фармацевтичних закладів повинні вміти виконувати самостійну роботу, включаючи при цьому свій внутрішній потенціал адаптації до поставлених перед ним завдань. Відповідно від того наскільки успішно буде проходити процес адаптації, буде залежати й успішність нав- чання студента та його становлення як майбутнього фахівця [1].

Розширення функцій і зростання ролі самостійної роботи студентів не тільки веде до збільшення iï обсягу, а й обумовлює зміну у взаємовідносинах між викладачем та студентом як рівноправними суб'єктами навчальної діяльності, привчаючи самостійно вирішувати питання організації, планування, контролю за своєю навчальною діяльністю, враховуючи самостійність як особисту рису характеру.

Цілеспрямована сукупність дій студента під керівництвом викладача на основі використання засобів супроводу навчального процесу передбачає самостійність - можливість здійснювати самостійну роботу на основі формування якостей рефлексивного керування, вивчення методів управління навчальнотворчою діяльністю студентів, набуття практичних навичок з аналізу і оцінки якості освітнього процесу за критеріями європейського освітнього простору [2].

Обгрунтування дослідження. Самостійна робота лежить в основі будь-якої освіти, є формою організації навчання та засобом оволодіння глибокими знаннями і практичними навичками [3].

Поняття «самостійна робота» використовується різними авторами у різних значеннях залежно 
від того, який зміст вкладається у поняття «самостійний»:

- студент виконує роботу сам, без посередньої участі викладача;

- студент самостійно мислить, досить глибоко орієнтується у навчальному матеріалі;

- студент виконує самостійну роботу під контролем викладача [4].

Самостійна робота студентів організовується за наступними принципами:

- комплексність підходу;

- високий рівень інтелектуальних труднощів: самостійна робота студента повинна ставити перед студентами високі інтелектуальні завдання, виконання яких вимагає певних зусиль;

- навчальний характер: студента необхідно навчити раціональним методам самостійної роботи;

- творчий характер: самостійна робота повинна формувати творчу особистість;

- індивідуалізація: забезпечення індивідуальних завдань для кожного студента 3 урахуванням його вікових, психологічних можливостей, знань, умінь і навичок, рівня пізнавального інтересу;

- поступовість переходу від контролю самостійної роботи студента 3 боку викладача до взаємо- $\mathrm{i}$ самоконтролю.

Такими заходами самостійної роботи з розвитку особистості майбутнього провізора на кафедрі фармації $\epsilon$ проведення студентських науковопрактичних конференцій, оволодіння уміннями i навичками в навчально-практичному центрі «Фармація», підготовка доповідей і презентацій при виконанні дипломних робіт тощо. При правильній організації з боку професорсько-викладацького складу кафедри, самостійна робота студентів, ставши основною формою навчання, забезпечує повноцінне засвоєння дисциплін.

Самостійна робота студентів перетворює їх за час навчання в університеті від пасивних споживачів знань до активних творців, які вміють сформулювати проблему і знайти шляхи ії вирішення [3].

Самостійна робота студентів $\epsilon$ обов'язковою складовою частиною навчального процесу і виправданим засобом оволодіння навчальним матеріалом.

Мета роботи. Аналіз (оцінка) сутності самостійної роботи студентів на кафедрі фармації як складової професійної підготовки майбутніх провізорів.

Матеріали і методи. Основою компетентного підходу має стати комплексність у педагогічній діяльності щодо організації та здійснення освітнього процесу, навчання, виховання, розвитку і професійної підготовки студентів до певного виду професійноорієнтованої діяльності, яка грунтується на когнітивній, діяльнісній та творчій компетентностях [2].

Для цього слід постійно раціоналізовувати навчальний процес шляхом удосконалення змісту, форм i методів навчально-пізнавальної діяльності студентів вищих навчальних закладів, що якнайкраще розвивало і формувало б їх творчі здібності [5].

Плануючи самостійну роботу студентів, необхідно враховувати перелік знань, умінь і навичок, передбачених освітньо-кваліфікаційною характеристикою спеціаліста [6].

Самостійну роботу студентів при вивченні дисциплін навчального плану у вищих навчальних закладах з використанням інформаційних технологій необхідно організовувати як цілісну систему:

- використання освітніх сайтів;

- роботи з електронними виданнями;

- виконання індивідуальних завдань;

- поточної атестації за допомогою електронного тестування як однієї із форм організації контролю за самостійною роботою студентів, оскільки вона виноситься на підсумковий контроль разом 3 навчальним матеріалом.

Результати дослідження. Самостійна робота студентів - головний резерв оптимізації навчального процесу і водночас потужний стимул розвитку активності та творчого потенціалу особистості.

Види самостійної роботи студентів передбачають:

1. Вивчення нового матеріалу: читання та конспектування літературних джерел інформації; перегляд відеозаписів.

2. Поглиблене вивчення матеріалу: підготовка до контрольних, практичних занять, виконання типових задач.

3. Вивчення матеріалу з використанням елементів творчості: розв'язання нестандартних задач; складання рефератів, доповідей із заданої теми.

4. Вдосконалення теоретичних знань і практичних навичок в умовах виробництва: навчальні практикуми; усі види практик.

Зростає роль особистості викладача вищої школи в організації, методичному забезпеченні та контролі самостійної роботи студентів. Окрім самостійного засвоєння знань, студенти мають опанувати методи аналізу, синтезу та узагальнення інформації.

У свою чергу контроль самостійної роботи студентів включає:

- перевірку конспектів, рефератів, розв'язаних задач, розрахунків, виконаних графічних вправ, індивідуальних завдань;

- відповіді на контрольні або тестові питання. Обговорення результатів. У сучасних умовах реформування системи освіти України набула актуальності проблема професійної підготовки майбутніх фахівців. Виходячи з усвідомлення цього, навчання у вищих навчальних закладах повинно бути методично обгрунтованим та досконало продуманим. У цьому контексті особливої актуальності та визначального значення набувають методика, методи, технології та техніки викладання дисциплін у вищих навчальних закладах України [7]. Власне навчальна база кафедри фармації формується на основі професорськовикладацького складу з презентаціями лекцій, методичного забезпечення лекційного та практичного матеріалів, самостійної аудиторної та позааудиторної підготовки, електронної бази підручників, основної і додаткової літератури, реферативних та контрольних робіт, а також оновлюваними базами тестових завдань до ліцензійних іспитів. 
Незважаючи на тісний зв'язок $з$ аудиторною роботою, позааудиторна робота має свої відмінності, a саме:

1. участь студентів у позааудиторній роботі добровільна, а на навчальному занятті - обов'язкова;

2. позааудиторні засоби мають невимушений характер і тому надають більші можливості для прояву самостійності студентів, їхньої ініціативності та творчості [5].

Під час такої самостійної роботи, коли відвідування заняття залежить саме від бажання студента, формуються необхідність постійного поновлення знань, самовдосконалення, самодисципліна та самоконтроль.

Висновки. Організація проведення самостійної аудиторної та позааудиторної роботи студентів повинні визначатися, виходячи із галузевих стандартів освіти. У контексті вище зазначеного, навчальновиховний процес студента на етапі вивчення базових фармацевтичних дисциплін повинен бути орієнтований на впровадження нових методик та інноваційних технологій. Це, у свою чергу, створюватиме умови для формування професійної компетентності майбутнього провізора, розвитку його творчого потенціалу, системної самостійної роботи студентів щодо оволодіння науковими знаннями.

\section{References:}

1. Yoltuhivskyi MV, Loyko LS, Tysevych TV. Pro stan i shiahy udoskonalennia orhanizatsii samostiinoi roboty studentiv. Halytskyi likarskyi visnyk. 2017; 4(24):39-43.

2. Robocha prohrama «Pedahohika vyschoi shkoly» dlya aspirantiv zi spetsialnosti - 101 «Ekolohia». Rozrobnyk: Nahaev Viktor Myhailovych, professor kafedry menedzhmentu orhanizatsii, d.p.n., professor. 2016, April, 20. P.30.

3. Sabadosh RV. Optymizatsya samostiinoi roboty studentiv u zakladakh vyschoi osvity medychnoho spryamuvannya / Art of medicine, 2018; 3:215-217.

4. Skrobach NV, Havrysh IT, Delva YV. Samostiina robota studentiv vyschykh navchalnykh zakladiv yak vazhlyvyi element suchasnoi pidhotovky fakhivtsiv. Halytskyi likarskyi visnyk, 2014; 2:110-111.

5. Petrushenko TO, Nikolishyna EV, Ilenko NM, Popovych IY, Lytovchenko IY. Dosvid pozaaudytornoi roboty zi studentamy na kafedri terapevtuchnoi stomatolohii. Medychna osvita, 2018; 1:108-111.

6. Yurak MZ, Neiko VIe, Dzvonkovska VV. Osoblyvosti orhanizatsii samostiinoi roboty na zaniattiakh z propedevtyky vnutrishnoi medytsyny. In: Kompetentnisnyy pidkhid u pidhotovtsi suchasnoho fakhivtsya : zbirnyk tez naukovo-metodychnoyi konferentsiyi $\mathrm{z}$ mizhnarodnoyu uchastyu. Ivano-Frankivsk, 2017. P.161-162.

7. Shevchyk LO, Kravets NYa. Zastosuvannya kvestu yak tekhnolohii praktyko-orientovanoho navchannia studentiv medychnuh vushchiv. Medychna osvita, 2018; 3:78-81.

\section{УДК $378.147+614.253 .4$ \\ ОРГАНИЗАЦИЯ САМОСТОЯТЕЛЬНОЙ РАБО- ТЫ СТУДЕНТОВ КАК СОСТАВЛЯЮЩАЯ ПРОФЕССИОНАЛЬНОЙ ПОДГОТОВКИ БУДУЩИХ ПРОВИЗОРОВ}

\section{В.А. Сологуб}

\author{
Ивано-Франковский национальный медицинский \\ университет, кафедра фармации, \\ 2. Ивано-Франковск, Украина, \\ ORCID ID: 0000-0001-7815-1587, \\ e-mail: nika.solo.ifnmu2021@gmail.com
}

Резюме. Самостоятельная работа - один из способов изучения дисциплины, неотъемлемая часть учебного процесса. Это позволяет глубоко усвоить материал, углубить умение и навыки в познавательной деятельности, активизировать творческое мышление и инициативу; способствовать выработке собственных приемов и методов познания, учит рационально организовывать и контролировать свое рабочее время.

В соответствии с Положением "Об организации учебного процесса в высших учебных заведениях", самостоятельная работа студента является основным средством усвоения студентом учебного материала во время, свободное от обязательных учебных занятий.

Целеустремленная совокупность действий студента под руководством преподавателя на основе использования средств сопровождения учебного процесса предусматривает самостоятельность - возможность осуществлять самостоятельную работу на основе формирования качеств рефлексивного управления, изучения методов управления, учебнотворческой деятельностью студентов, приобретения практических навыков, из анализа и оценки качества образовательного процесса за критериями европейского образовательного пространства.

Среди мероприятий - усвоение в полном объеме учебной программы, определить эффективные методики и методологии преподавания учебных дисциплин в системе университетского образования, ее организации с учетом современных требований относительно качества общих и профессиональных компетентностей, которые играют существенную роль в становлении будущего специалиста высшего уровня квалификации.

В статье рассматриваются особенности организации самостоятельной работы студентов с учетом современных требований и условий учебы, методы ее эффективной организации как неотъемлемой составляющей в системе образовательной среды.

Ключевые слова: самообразование, самоконтроль, информационные технологии учебы. 
UDC 378.147+614.253.4

STUDENT INDEPENDENT WORK ORGANIZATION AS A COMPONENT OF PROFESSIONAL TRAINING OF FUTURE PHARMACISTS

\section{V.A. Solohub}

Ivano-Frankivsk National Medical University, Pharmacy Department, Ivano-Frankivsk, Ukraine, ORCID ID: 0000-0001-7815-1587, e-mail:nika.solo.ifnmu2021@gmail.com

Abstract. Students of higher medical and pharmaceutical institutions should be able to perform their own work, including their internal capacity to adapt to their tasks. Accordingly, the success of the training of students and becoming a future specialist will depend on successful adaptation process.

The wide range of functions and the growth of the role of independent work of students do not only lead to an increase in its volume, but also cause a change in the relationship between teacher and student as equal subjects of educational activity, accustom to independently solve the issues of organization, planning, control over educational activities and can teach a person to become more independent.

In accordance with the Regulation "On the organization of the educational process in higher educational institutions," the student's independent work is the main means of student's learning of the material at the time, free of compulsory training.

The purposeful set of actions of the student under the guidance of a teacher based on the use of means of maintenance of the educational process and involves independence - possibility to carry out selfdone work on the basis of formation of qualities of reflexive management, studying methods of management of educational and creative activity of students, acquiring practical skills for the analysis and evaluation of the quality of educational process according to the criteria of the European educational regulations.

When planning independent work of students, it is necessary to take into account the list of abilities, skills and knowledge, which are provided by the educational qualification of a specialist.

The term "independent work" is used by different authors in different meanings, depending on what content is put into the concept of "independent":

- the student does work himself, without the teacher's indirect participation;

- the student independently thinks, deeply oriented in the educational material;

- the student does an independent work under the supervision of a teacher.

During such independent work, when the attendance of a class depends on the student's desire, there is a need for constant renewal of knowledge, self-improvement, selfdiscipline and self-control.

Independent work of students in studying the curriculum disciplines in higher educational institutions with the use of information technologies should be organized as a holistic system that consists of:

- $\quad$ using educational sites;

- $\quad$ working with electronic publications;

- $\quad$ solving individual tasks;

- the current certification through electronic testing, as one of the forms of organizing control over the independent work of students, because it is put on the final control together with the educational material.

The organization of conducting independent and extra-curriculum work of students must be determined because of industry standards of education. The educational student's process at the stage of studying basic pharmaceutical disciplines should be focused on the introduction of new techniques and innovative technologies. This will create conditions for the formation of the professional competence of the future pharmacist, the development of creative potential, and systemic independent work of students on mastering scientific knowledge.

Keywords: self-education, self-control, information technology of training.

Стаття надійшла в редакцію 01.04.2019 p. 